\title{
Languages of Law: Islamic Legal Cosmopolis and its
}

\author{
Arabic and Malay Microcosmoi
}

\section{MAHMOOD KOORIA}

\begin{abstract}
In premodern monsoon Asia, the legal worlds of major and minor traditions formed a cosmopolis of laws which expanded chronologically and geographically. Without necessarily replacing one another, they all coexisted in a larger domain with fluctuating influences over time and place. In this legal cosmopolis, each tradition had its own aggregation of diverse juridical, linguistic and contextual variants. In South and Southeast Asia, Islam has accordingly formed its own cosmopolis of law by incorporating a network of different juridical texts, institutions, jurists and scholars and by the meaningful use of these variants through shared vocabularies and languages. Focusing on the Shäfi $i$ School of Islamic law and its major proponents in Malay and Arabic textual productions, this article argues that the intentional choice of a lingua franca contributed to the wider reception and longer sustainability of this particular legal school. The Arabic and Malay microcosmoi thus strengthened the larger cosmopolis of Islamic law through transregional and translinguistic exchanges across legal, cultural and continental borders.
\end{abstract}

Keywords: Shaf ${ }^{i}{ }^{-}{ }^{-}$School; Malay and Arabic textual productions.

\section{Introduction}

Law was one of the most important realms that set frameworks for transregional interactions among individuals, communities and institutions in the premodern world. It synchronised structures of exchange through commonly agreed practices and expectations. ${ }^{1}$ The written legal treatises, along with unwritten customs, norms and rituals, prescribed ideal forms of social, cultural, economic and political relations to maintain order, peace and affinity in the societies in which they operated. These written and unwritten laws influenced each other in the long run both internally and externally through spatial and temporal concurrences. While the unwritten laws of the premodern world may be inaccessible, the written

\footnotetext{
${ }^{1}$ On the role of law in the global interactions between I 400 and I $800 \mathrm{CE}$, see Lauren Benton and Adam Clulow, 'Legal encounters and the origins of global law', in The Cambridge World History, Volume 6: The Construction of a Global World, 1400-1800 CE, Part 2: Patterns of Change, (eds.) Jerry H. Bentley, Sanjay Subrahmanyam and Merry E. Wiesner-Hanks (Cambridge, 20I5), pp. 80-100.
}

(C) The Royal Asiatic Society 2019. This is an Open Access article, distributed under the terms of the Creative Commons Attribution-NonCommercial-NoDerivatives licence (http://creativecommons.org/ licenses/by-nc-nd/4.0/), which permits non-commercial re-use, distribution, and reproduction in any medium, provided the original work is unaltered and is properly cited. The written permission of Cambridge University Press must be obtained for commercial re-use or in order to create a derivative work. 
texts provide a rich archive to understand the ways in which the communities struggled towards constructing an ideal world through the active and passive conversations of individual communities and institutions. In monsoon Asia, the legal worlds of Buddhism, Hinduism and Islam, along with several minor traditions indigenous to specific lands and times, formed a cosmopolis of laws which expanded chronologically vertically and geographically horizontally. In the premodern period no tradition replaced another entirely. Instead, they all coexisted in a larger domain with fluctuating influences over time and place. ${ }^{2}$ Within this legal cosmopolis, each tradition and religion had its own aggregation of diverse juridical, linguistic, geographical and chronological variants. In South and Southeast Asia, Islam has accordingly formed its own cosmopolis of law by incorporating a network of different juridical texts, languages, institutions and scholars and by the meaningful use of these variants through shared vocabularies. The predominance of particular streams of law over others in the course of time was the outcome. This article explores the nuances of such formations and formulations, with a close examination of Arabic and Malay textual productions of Islamic laws in South and Southeast Asia. It delineates the extent to which Islam and its law facilitated reciprocation between people from both those subcontinents.

The burgeoning scholarship of the last decade on the circulations of law within the Indian Ocean rim, from East Africa to East Asia, has persuasively demonstrated the centrality of law for transregional and trans-imperial interactions in the premodern and modern world. ${ }^{3}$ The maritime networks of scholars, lawyers, courts, codes and texts facilitated multi-directional transfers of laws across regional and religious boundaries. Engseng Ho, Nurfadzilah Yahya and Sumit Mandal have explored how itinerant communities, such as the Hadramis and other Arabs, grappled with the juridical notions inherent to Islam in the oceanic littoral, simultaneously compromising and conflicting with local religious ideas and with external and dominant imperial, colonial and post-colonial judicial structures. ${ }^{4}$ Through a historical anthropological approach to legal documents, Brinkley Messick has showed the microscopic nature of juridical production and dissemination by the political-cum-scholarly entities. ${ }^{5}$ Iza Hussin, Fahad Bishara, and Joel Blecher have emphasised the criss-crossing of legal ideas across the maritime littoral. This exposed the role of legal codes and documents in the continuum of local and trans-local communities in everyday matters concerning politics, trade and diplomacy. ${ }^{6}$ For most individuals participating in such transregional networks of the socio-economy, an

${ }^{2}$ Tom Hoogervorst, 'Legal diglossia, lexical borrowing and mixed judicial systems in early Islamic Java and Sumatra', in Ocean of Law: Islamic Legal Crossings in the Indian Ocean, (eds.) Mahmood Kooria and Sanne Ravensbergen (Leiden, Brill, forthcoming).

${ }^{3}$ For two collective attempts, see the contributions in special issues of journals: Mahmood Kooria and Sanne Ravensbergen, (eds.) 'Indian Ocean of Law: Hybrid Mobilities', Itinerario 43, no. 3 (2018), pp. I 5 I-290; Renisa Mawani and Iza Hussin, (eds.) 'The Travels of Law: Indian Ocean Itineraries', Law and History Review 32, no. 4 (20I4), pp. 733-889.

${ }^{4}$ Engseng Ho, Graves of Tarim: Genealogy and Mobility across the Indian Ocean (Chicago, 2006); Sumit Mandal, Becoming Arab: Creole Histories and Modern Identity in the Malay World (Cambridge, 20I7); Nurfadzilah Yahaya, 'Courting jurisdictions: Colonial administration of Islamic law pertaining to Arabs in the British Straits Settlements and the Netherlands East Indies, I860-I94I', Ph.D. diss., Princeton University, 2012.

${ }^{5}$ Brinkley Messick, Shari'a Scripts: A Historical Anthropology (New York, 20I8); idem, The Calligraphic State: Textual Domination and History in a Muslim Society (Berkeley, I992).

${ }^{6}$ Iza R. Hussin, The Politics of Islamic Law: Local Elites, Colonial Authority, and the Making of the Muslim State (Chicago, 2016); Fahad Bishara, A Sea of Debt: Law and Economic Life in the Western Indian Ocean, 1780-1950 (Cambridge, 20I7); Joel Blecher, Said the Prophet of God: Hadith Commentary Across a Millennium (Berkeley, 20I7). 
item in a legal document and in supporting texts or codes provided a basis for the legitimacy of their profession, possession, and power. These aspects, in turn, provide us potential materials to identify "thick trans-regionalism" embedded in the materials produced by the diverse mobile maritime communities of Asia and Africa. ${ }^{7}$ All these recent studies not only exemplify the growing literature on different kinds of circulations of law, texts, people and institutions in the Indian Ocean littoral, but they also highlight the role of Islamic law in such circulations, both in the premodern and the modern periods, before and after European colonial empires dominated the sphere of law. In these studies, however, the role of language has been seriously marginalised when considering the production, dissemination and practice of law.

In the religious and juridical encounters across the borders of continents and subcontinents language barriers must have been a huge obstacle for participant groups and individuals who came from a wide range of regional, linguistic, ethnic and cultural backgrounds. How did people overcome this obstacle legalistically and linguistically? The works of Sheldon Pollock on the Sanskrit cosmopolis and Ronit Ricci's study on the Arabic cosmopolis in South and Southeast Asia have answered some aspects of this question, when they suggest that Sanskrit and then Arabic stood as the lingua franca for literary and cultural productions in both regions. ${ }^{8}$ Ricci's work is more related to the focus of this article, but she does not deal with the function of the language in the legal realm per se. In fact language is certainly one of the most important aspects, if not the most important, of trans-regional law, be it for plaintiffs, defendants, witnesses, audiences, evidence, texts, codes or general court procedure. I have elsewhere addressed this question with regard to foreign languages and translations in early Islamic judicial procedures, but we know hardly anything about its role in such multi-linguistic, multi-ethnic, and multi-religious contexts as that of the Indian Ocean, apart from an insightful article by Henri Chambert-Loir on the language of the law in seventeenth-century Aceh. ${ }^{9}$ In this article he enters this gap in dialogue with the aforementioned literature where it concerned the circulations of communities, institutions and individuals in the littoral and their trans-regional interactions between South and Southeast Asia, principally in Malay and Arabic.

How and why did the participants from both subcontinents leave the comfort zones of their own languages to address local and wider audiences? What were the implications of their efforts to cross linguistic boundaries? Did their attempts lead to one particular variant of Islamic law, that of the Shăfi $1 \overline{1}$ School, as the predominant school of legalistic and intellectual engagement, at a time when there were several other forms and streams of laws? This article addresses these questions by focusing on some significant legal texts and jurists who contributed to the strengthening of Islam and its law in monsoon Asia. These texts and scholars adhered to one of two major language microcosmoi of the oceanic littoral. Emphasising this aspect I argue that because one particular Islamic legal stream took varying linguistic and

\footnotetext{
${ }^{7}$ Engseng Ho, 'Afterword: Mobile Law and Thick Transregionalism', Law and History Review 32, no. 4 (20I4), pp. $883-889$.

${ }^{8}$ Sheldon Pollock, The Language of the Gods in the World of Men: Sanskrit, Culture, and Power in Premodern India (Berkeley, 2006); Ronit Ricci, Islam Translated: Literature, Conversion, and the Arabic Cosmopolis of South and Southeast Asia (Chicago, 20 I I).

${ }^{9}$ Mahmood Kooria, 'Words of 'Ajam in the World of Arab: Translation and Translator in Early Islamic Judicial Procedure', Justice and Leadership in Early Islamic Courts, (eds.) Intisar Rabb and Abigail Balbale (Cambridge, 20I 8), pp. 7I-90; Henri Chambert-Loir, 'Islamic Law in I7th Century Aceh', Archipel 94 (20I7), pp. 5I-96.
} 
cultural contexts into its consideration, it managed to dominate South and Southeast Asian coastal communities and to find wider acceptance among more adherents. The circulation of Islam and its laws did not promote or insist on a monolithic language cosmopolis (pace the Arabic cosmopolis, suggested by Ronit Ricci). Arabic was a lingua franca in this littoral, but it was not the only one from the sixteenth to the nineteenth centuries. It coexisted with several other powerful languages through which the Muslim missionaries, mariners and merchants communicated with each other in their everyday meetings at markets, mosques and manors. In the premodern Indian Ocean rim there existed several other language cosmopolises, as when Persian, Portuguese, Swahili and Malay coexisted with Arabic. ${ }^{10}$ In South and Southeast Asia, Malay and Arabic contributed equally to the spread and survival of Islam in general and of its law in particular. ${ }^{11}$

An intentional selection of the language for writing works of law contributed to the sustenance of Shāfi 'ì legalism in the Indian Ocean littoral. Involving one or more languages with Arabic has been crucial to the sustainability of any of the intellectual networks of Islam and particularly of legal schools, as we see in the Hanafi realms of Mughal South Asia and the Ottoman Near East, as well as in the Mālikī domains of the North Africa and Andalusia and the Shī'î sphere of Șafavid Persia. Legal compilations in Arabic were complemented by those in Turkish and Persian and several other languages. Shāfi '̄ssm did this through the attention and ability of its scholars to write in both Arabic and the regional lingua franca. An open approach among those jurists to navigate between these languages played an important role in making their school the dominant one in the Indian Ocean world from the sixteenth century onwards. This resonates very much with the trajectories of the French civil code (Code civil des Français, widely known as the Code Napoleon) in the nineteenth century across several countries of Europe and the Americas, Africa and Asia, where French was considered to be the language of civil law while the jurists simultanously facilitated its communication with, and translation into, several other regional or national languages. ${ }^{12}$

In the following pages I shall explore these nuances: I start by analysing the capacity of law and language to connect monsoon Asia, in which an Islamic legal cosmopolis strengthened the increasing mobility of scholars, sailors and traders, with shared expressions and understandings from the sixteenth century onward. In the next section I shall describe some of the most important legal texts from South and Southeast Asia written in Arabic and Malay. The texts Qurrat al- 'ayn by a Malabari scholar Zayn al-Dīn bin Ahmad (d. I583?) and its commentary Nihāyat al-zayn by a Javanese scholar 'Umar Nawaw̄ al-Bantan̄̄ (d. I898) represent the Arabic microcosmos of the Shāfi 1 l legal cosmopolis, whereas Sirāt

\footnotetext{
${ }^{10}$ Jos Gommans, 'Continuity and Change in the Indian Ocean Basin', in The Cambridge World History, Vol.6: The Construction of a Global World, 1400-1800 CE, (eds.) Jerry H. Bentley, Sanjay Subrahmanyam and Merry E. Wiesner, (Cambridge, 2015), pp. I82-209. On the use of Persian as a lingua franca in the littoral and its existence in a Persian cosmopolis, see Gagan Sood, India and the Islamic Heartlands: An Eighteenth-Century World of Circulation and Exchange (Cambridge, 20I6); Tomáš Petrů, "Lands below the Winds' as Part of the Persian Cosmopolis: An Inquiry into Linguistic and Cultural Borrowings from the Persianate societies in the Malay World', Moussons 27 (20I6), pp. I47-I6I; Owen Cornwall, 'Alexander and the Persian Cosmopolis, I000-I500', Ph.D. diss., Columbia University, 2016."

${ }^{11} \mathrm{On}$ the role of Arabic language in the legal literature of Malabar in South Asia, see Husayn C. S., 'Musāhamāt 'ulamā' Kayralā fì al-adab al-fiqh bi al-lughat al-'Arabiyya,' PhD diss., University of Calicut, 2004.

${ }^{12}$ David Mellinkoff, The Language of the Law (Eugene, 2004), pp. 95-135; cf. Bernard Schwartz, (ed.) The Code Napoleon and the Common-law World (New York, I956).
} 
al-mustaqìm by Nūr al-Dīn al-Ranīñ̄ of Gujarat (d. I658) and its commentary Sabīl al-muhtadīn by Muhammad Arshad al-Banjārī of Kalimantan (I7IO-I8I2) epitomise its Malay microcosmos. I shall focus on the aspect of language in these texts in the last section of the chapter and conclude by highlighting the role of local and trans-local linguistic and cultural contexts that enabled the spread and survival of one specific school of law among the Muslim communities of oceanic littoral.

\section{Locating Law and Language}

Islamic connections between South and Southeast Asia can be traced to the early centuries of Islamic expansion in those regions. ${ }^{13}$ There are accounts of South Asian Muslim preachers, scholars and merchants arriving in Southeast Asian kingdoms and regions and spreading Islam through different engagements and encounters. One important trend in historiography, though now outdated, asserts the origin of Islam in the Malay world to Indian Muslim itinerants, particularly from Gujarat, Bengal, Coromandel and/or Malabar. Some pseudo-historical figures, such as Maulana Naina bin Naina al-Malabari, dominate mythological narratives on the early Islamic connections between these regions and the expansion and endurance of Islam in the archipelago. Some of these narratives are clearly anachronistic and have yet to be verified on the basis of solid historical evidence. What solid evidence we do have for connections from the thirteenth century onward consists of fragmentary tombstones and inscriptions. ${ }^{14}$

From the sixteenth century onward such Islamic connections between both subcontinents intensified at an unprecedented pace through religious and intellectual exchanges. There was a growing presence of South Asian authors, scholars, soldiers, teachers and preachers in Southeast Asia, as more and more Southeast Asians arrived in India and Sri Lanka as travellers, traders, exiles, scholars, sailors and soldiers. This movement of people had implications for the circulation of ideas about features of Islamic law from the sixteenth century onward. In that century the Shāfi ${ }^{\prime} \bar{i}$ School of Islamic law began to dominate the coasts of both subcontinents along with several other parts of the Indian Ocean littoral, with the ideas and texts of the school becoming apparent in scholarly exchanges. This provided the common ground on which jurists of monsoon Asia interacted.

Although the arrival of European powers in the Indian Ocean interrupted the Middle Eastern predominance in maritime trade it did not affect the existing networks of Islamic people, texts and ideas. Rather it streamlined their mobility through standard forms of Islamic legal and mystical cultures, such as the Shāfi 1 School of law and the Shatțāina order of Sufism. In coastal South Asia and Southeast Asia both the legal school and the mystical order had established varying degrees of presence and influence in the sixteenth century, if not before. The Shattatariya order was followed in the coastal belts of Gujarat, Konkan, Malabar, Coromandel and Bengal in that century, along with other mystical orders,

\footnotetext{
${ }^{13}$ For an overview of the Islamic connections between both subcontinents, see R. Michael Feener and Terenjit Sevea, (eds.) Islamic Connections: Studies of South and Southeast Asia (Singapore, 2009).

${ }^{14}$ Elizabeth Lambourn, 'Carving and Communities: Marble Carving for Muslim Patrons at Khambhāt and Around the Indian Ocean Rim, Late Thirteenth-Mid-Fifteenth Centuries', Ars Orientalis 34 (2007), pp. 99-I33; idem, "From Cambay to Samudera-Pasai and Gresik: the Export of Gujarati Grave Memorials to Sumatra and Java In the Fifteenth Century CE”, Indonesia and the Malay World 3 I, no. 90 (2003), pp. 22 I-284.
} 
including Qādiriyya, Naqshabandiyya, and Kāzarūniyya. It also found followers in Aceh, Sumatra, Java, Perak and Sulawesi. ${ }^{15}$ The interconnectivity between both regions in terms of mystical ideas is yet to be explored, but for the moment suffice to say that the mystical orders often formed a stepping stone for itinerants to share their understanding of Islam with their hosting communities, future coreligionists and even nascent opponents.

Apart from the essential elements of the religion and the related rituals and laws which constituted it, the nuanced legalistic engagements were often secondary to initial interactions. Even so, it is hard to generalise for all the regions in South and Southeast Asia. The consensus among historians of Southeast Asian Islam is that mystical (or perhaps mythical) figures and groups, such as nine holy men (Walisongo), spread Islam in the region, and legal schools like Shāfi 'ism entered much later. Often the followers of the religion showed little interest in legalised interpretations of Islam. As an example Muhammad al-Ḥāmid al-Ranīiñ, an Islamic jurist in the court of the Aceh Sultanate in the late-sixteenth century, is often quoted. He had to quit the place because the students were not interested in learning law. ${ }^{16} \mathrm{He}$ left for Mecca/Hijaz in I 583 to study Sufism and came back six years later to teach mysticism to his old and new audience. From I 589 he taught there until I604. This predominance of mysticism continued in Aceh in the seventeenth to nineteenth centuries, as most of the textual productions from the region indicate. ${ }^{17}$ The law marked its strength in the everyday practice of rituals and as a basic curriculum, but it continued be nominal as an advanced discipline of higher education and school of thought. ${ }^{18}$ In coastal South Asia too Islamic legal thought as such was marginal until the mid-sixteenth century, but from then we find more textual productions based on the positive legal thought. In Malabar, Gujarat, Sind and Coromandel there was notable production and dissemination of mystical works until the early sixteenth century, but by the mid-sixteenth century more works appear on Islamic law.

This scarcity of legal texts in both regions does not mean that Islamic law was not at all present. We have strong evidence of Muslims in monsoon Asia following the practice of Islamic legal schools at different levels from as early as the eighth century. ${ }^{19}$ Until the sixteenth century we have an intermixed legal system, in that many different Sunn̄i, Shī'i and Ibādī legal traditions coexisted and operated in different regions. As most followers were Sunnīs in monsoon Asia, the important schools followed in the regions there were

\footnotetext{
${ }^{15}$ Sebastian Prange, Monsoon Islam: Trade and Faith on the Medieval Malabar Coast (Cambridge, 201 8); Jyoti Gulati Balachandran, 'Texts, tombs and memory: the migration, settlement, and formation of a learned Muslim community in fifteenth-century Gujarat', PhD thesis, University of California, Los Angeles, 2012; Azyumardi Azra, The origins of Islamic reformism in Southeast Asia: networks of Malay-Indonesian and Middle Eastern ulama in the seventeenth and eighteenth centuries (Honolulu, 2004); Richard Eaton, Sufis of Bijapur, 1300-1700: Social Roles of Sufis in Medieval India (Princeton, I978); Tayka Shu'ayb 'Ālim, Arabic, Arwi, and Persian in Sarandib and Tamil Nadu: A Study of the Contributions of Sri Lanka and Tamil Nadu to Arabic, Arwi, Persian, and Urdu languages, literature, and education (Madras, I993); Oman Fathurrahman. Tarekat Syattariyah Di Minangkabau (Jakarta, 2007); Anthony Johns, Malay Sufism as illustrated in an anonymous collection of 17th century tracts (Oxford, I957).

${ }^{16}$ Nūr al-Dīn al-Ran̄īī, Bustan al-salatin Bab II, Pasal 13, (ed.) T. Iskandar (Kuala Lumpur, I966), p. 33.

${ }^{17}$ Erawadi. Tradisi, wacana, dan dinamika intelektual Islam Aceh abad XVIII dan XIX (Jakarta, 2009).

${ }^{18}$ Mohammad Hannan Hassan, 'Islamic legal thought and practices of seventeenth-century Aceh: treating the others', PhD diss., McGill University, 2014; Chambert-Loir, 'Islamic Law in I 7th Century Aceh'.

${ }^{19}$ Mahmood Kooria, The Formation of Islamic Law in the Indian Ocean Rim, c. 615-I000 CE', in Ocean of Law: Islamic Legal Crossings in the Indian Ocean, (eds.) Mahmood Kooria and Sanne Ravensbergen (Leiden, forthcoming).
} 
Hanafîsm, Shāfi '̄̄sm and Mālikīsm. For example we note references found at Hanafì mosques and institutions in Demak, Gujarat, Coromandel Coast, to a Mālikī mosque and followers in the Maldives and Malabar, and to Shī iss and Ibādīs in Sind. All these schools coexisted with the Shāfi 'i School which was clearly evident in Sumatra and Malabar from the fourteenth century onward. ${ }^{20}$ But by the sixteenth century the Shāfi 1 School began to dominate the littoral. This was due to a number of reasons, but mainly to the upsurge of Persian, Yemeni, Swahili and Malay migrants, exiles, sailors and scholars in the littoral. There was also an increasing number of conversions to Islam and within Islam to Shāfi '̄sm at the hands of new missionaries, in an attempt to escape enslavement by Arab Muslim slavers who were theoretically prohibited from enslaving coreligionists. ${ }^{21}$

As Islam and its legal frameworks expanded in these regions interactions between scholars, preachers, jurists, pilgrims and other itinerants from both subcontinents mutually influenced the spiritual and legal formulations. The nuances of these reciprocated influences become clear in our following discussion on the legal texts. One immediate hurdle obstructing transregional exchanges must have been language. In South and Southeast Asia a wide range of languages was spoken in the coastal regions, and most of the itinerants had a vernacular language as their mother tongue. The lingua franca that existed across the monsoon Asia overcame this hurdle for most purposes. Earlier scholarship has enlightened us on the modulations of linguistic negotiations from the ancient period onward. In his conceptualisation of a Sanskrit cosmopolis, Sheldon Pollock suggested Sanskrit was a lingua franca between both these subcontinents from fifth to the fifteenth century. Following his framework, Ronit Ricci argued that Arabic replaced Sanskrit as a lingua franca in South and Southeast Asian interactions from the fifteenth century onward. Tomáš Petrů, Owen Cornwall and Richard Eaton have recently added the role of Persian that formed its own cosmopolis to the earlier two metanarratives. ${ }^{22}$ I shall not argue for or against the dominance of any particular linguistic cosmopolis in monsoon Asia but suggest that all three languages, and in addition Malay, Portuguese and Tamil, were significant factors in the trans-regional exchanges between both subcontinents from the late sixteenth century onward. For Islam and Islamic law the microcosmoi of Arabic and Malay mattered most in this period and the production and circulation of the texts and scholarship in these languages contributed to the success of the Shāfi 's school of law. The legal texts produced in both South and Southeast Asia validate this point, to which I turn my attention now.

\section{Texts and Textures of Law}

A significant amount of Arabic works was begun to be produced in monsoon Asia as early as the fourteenth century. Despite suggesting an Arabic cosmopolis in South and Southeast

\footnotetext{
${ }^{20}$ Abū 'Abd Allāh Muhammad bin 'Abd Allāh Ibn Bațțūta, Rihlat Ibn Batțūta: Tuhfat al-nuzzāa fī gharā'ib al-amșār wa- 'ajā'ib al-asfầr, (ed.) Muhammad 'Abd al-Mun ìm al-'Uryān and Musṭafā al-Qaș̣āṣ (Beirut, I987), pp. $63 \mathrm{I}-632$.

${ }^{21}$ Mahmood Kooria, 'Cosmopolis of law: Islamic legal ideas and texts across the Indian Ocean and eastern Mediterranean worlds', PhD diss., Leiden University, 2016.

${ }^{22}$ Petrů, 'Lands below the Winds'; Cornwall, 'Alexander and the Persian Cosmopolis'; Richard Eaton, 'The Persian Cosmopolis (900-1900) and the Sanskrit Cosmopolis (400-I400)', in The Persianate World: Towards a Conceptual Framework, (ed.) Abbas Amanat (Leiden, forthcoming).
} 
Asia, Ricci did not pay attention to the texts written in Arabic in these subcontinents. Her focus was on the works that came out as direct or indirect translations of Arabic texts and the ways in which Arabic vocabularies, imaginaries, and scripts were domesticated by the Tamil, Malay and Javanese Muslim authors. As for writings on Islamic law in monsoon Asia, works written in Arabic are rather prominent and important. For most authors from these regions Arabic was the most convenient medium to share their ideas and to mark their presence in regional and transregional literary spheres.

A few fragmentary legal writings available in the littoral from the fourteenth century onward are directly related to the Shāfi ${ }^{1}$ School of law itself. From South Asia we have a fourteenth-century text entitled Qayd al-jāmi by one Faqīh Husayn bin Ahmad. ${ }^{23}$ It deals with marital rules, proceedings and requirements according to Shāfi îssm. We do not have details about its author, apart from a possible reference Ibn Battūta makes to one Faqīh Husayn in his discussion on a miraculous tree found in Malabar. ${ }^{24}$ Another important Shāfi' $\overline{1}$ text from the littoral, Kashf al-durar fì sharh al-Muharrar by Shihāb al-Dīn Aḥmad bin Yūsuf al-Sindī (d. I 490) is connected to Sind. It is one of the only two known commentaries on the Muharrar by Rāfi $\overline{1}$ (d. I227), a leading scholar of the school. ${ }^{25}$ Although again we do not have much biographical information on this author, his patronymic Sindin indicates the place with which his family was associated or where he was based. From Southeast Asia, we do not get a complete Arabic legal text until the nineteenth century. Instead, we have a few fragmentary Islamic legal documents from the early fourteenth century. The Terengganu Inscription is the most important among these. In this edict, written in I3O2 in Malay with twenty-nine Sanskrit words and ten Arabic words, the king adjudicates the punishment for crimes such as adultery according to Islamic law. ${ }^{26}$ Otherwise we have a few general legal codes, such as the Undang-Undang Melaka, which do not claim to follow any Islamic legal stream yet incorporate several Islamic legal principles and rulings on marriage, sale and procedure. ${ }^{27}$ This split between the Arabic and Malay microcosmoi of monsoon Asia in the language of religion and law is an interesting phenomenon. The languages enable a shared Islamic legal cosmopolis through interconnected languages, laws and translations. The four prominent texts written by some of the most known jurists from the region represent this wider spectrum.

First, the Qurrat al- 'ayn by Zayn al-Dīn bin Ahmad is probably the earliest known complete text on Shāfi 1 law from South Asia. It was written before I 575 as a concise introductory text (mukhtasar) to Shāfi ${ }^{\prime} \overline{1}$ law. Its author is said to have written several other texts dealing with legal, historical and ethical issues and he is one of the most celebrated Indian Shāfi ${ }^{\prime} \bar{y}$ jurists. Even so, we do not have much solid evidence on his life and career. According

\footnotetext{
${ }^{23}$ K. M. Muhammad, Arabi Sāhityattinu Kēralattinte Saṃbhāvana (Tirūrannāṭi, 2012), pp. 62-63.

${ }^{24}$ Ibn Battūta, Rihla, p. 574. The local scholars believe that both Husayns are the same. Muhammad, Arabi Săhityattinu, p. 62.

${ }^{25}$ Aḥmad Mayqarī Shumaylat al-Ahdal, Sullam al-Muta' allim al-muhtāj ilā ma 'rifat rumuz al-Minhāj, (ed.) Ismā' îl 'Uthmān Zayn (Jeddah, 2005), pp. 630-63I.

${ }^{26}$ Ayang Utriza Yakin, 'Dialectic between Islamic Law and Adat Law in the Nusantara: A Reinterpretation on the Terengganu Inscription in the I 4 th Century', Heritage of Nusantara: International Journal of Religious Literature and Heritage 3, no. 2 (20I4), pp. 293-3 2.

${ }^{27}$ Liaw Yock Fang, Undang-Undang Melaka: The Laws of Melaka (The Hague, I976).
} 
to the popular narratives and uncritical scholarly writings, he is said to have been born into a scholarly family, generally known as the Makhdūms, who had migrated from the Coromandel Coast to Cochin and Ponnāni in the Malabar Coast. ${ }^{28}$ He was educated with his father and uncle in the mosque-cum-college of Ponnāni as well as in Mecca with reputed scholars of his time. He authored the Qurra upon his return from Arabia, a text that would eventually become the base text for several commentaries and super-commentaries among the Shāfi ${ }_{1} \overline{1}$ jurists in South and Southeast Asia as well as in the Middle East and East Africa. ${ }^{29}$ It has one commentary, written by the author himself in the sixteenth century, which is widely known and studied in the traditional centres of Shāfi $1 \overline{1}$ learning across the littoral.

In its overall approach and structure, the Qurra is just like any other mukhtaṣar text written in the long textual genealogy of the school. It deals with four broad major sections of a Shāfi ' 1 text: laws related to rituals, transactions, marriage and crimes. The text does not classify its chapters as such, but has individual chapters on the laws of prayer, almsgiving, fasting and pilgrimage (all related to rituals); on the laws of sale, power of attorney (devolved authorisation), loan, rent, debt, gift, endowment, declaration and inheritance (all related to transactions); on marriage; and on crimes, apostasy, punishments, holy war, adjudication, case law and evidence, and manumission (all part of crimes). The organisation of the chapters is haphazard, yet it follows a general pattern found in Shāfí ${ }^{\prime} \overline{1}$ law books in categorising and structuring legal issues. ${ }^{30}$ There are only a few aberrations: it starts with a discussion on laws of prayer, in contrast to other texts in the school which start with a discussion on laws of purity. Starting with the obligation of prayer and its requirements, the Qurra then comes to ritual purity and moves on to other issues. Many chapters have separate subsections, which the author identifies with the term faṣl (an Arabic term indicating a paragraph or article). This sub-sectioning is similarly imbalanced, as some chapters do not have any subsections while there are up to ten subsections for chapters on prayer, sale and marriage.

The Qurra is a very concise text that it just meets the requirements of a book and escapes the framework of a pamphlet. The extremely precise formulations do not engage with the previous discourses in the school on any legal problems, but directly describe and pronounce rulings for each issue. All these aspects might make it an intellectually unengaging and uninteresting text for specialist readers, but it catered to the needs of a general audience whom the author probably had in mind. ${ }^{31}$ Its rulings always confirm the most valid views in the school, and occasionally provide apt opinions for actual problems the author had encountered in his life related to socio-cultural issues in his immediate context. Through this text readers could start learning the basic principles and requirements of Islamic law, even if they were not interested in the rigorous legal debates of earlier scholars on each issue. Since

\footnotetext{
${ }^{28}$ For some hagiographical and biographical writings on him, see Rafĩq 'Abd al-Barr al- Wāfî, 'al-Juhūd al-fiqhiyya li al-Imām Aḥmad Zayn al-D̄̄n al-Makhdūm al-Malaybārī wa duwaruhu fì nashr al-Madhab alShāfi '̄i fì al-Hind', PhD diss., al-Azhar University, 20I4; Husain Raṇtattāṇi, Makhdūmum Ponnāniyum (Ponnāni, 2010); Muhamed Kunju P., 'The Makhdums of Ponnani', PhD diss., University of Kerala, 2004); O. P. Mayankutty, 'Role of Makhdums in the Anti-Colonial Struggles of Sixteenth-Century Malabar', PhD diss., Calicut University, 2007.

${ }^{29}$ al-Malaybārī, 'Qurrat al-'ayn bi muhimmāt al-dīn', in his Fath al-mu ìn bi sharh Qurrat al- 'ayn (Kottakkal, n.d).

${ }^{30} \mathrm{On}$ the general pattern of chapterisation in the Shāfi '̇ legal texts, see 'Abd al-Wahhāb Ibrāhīm Abū Sulaymān, Tartīb al-mawd̄̄ 'àt al-fiqhiyya wa munāsabatuh fì al-madāhib al-arba'a (Mecca), pp. 59-69.

${ }^{31}$ al-Malaybārī, 'Qurrat al-'ayn', p. 4.
} 
the text is very short, any student could memorise it easily, following the general practice in the Islamic world for learning important texts by heart. For the systematic expansion of the Shāfi $\overline{1}$ ideas through primary level introduction to the Islamic rituals and laws, this sort of introductory text contributed more efficiently than any other advanced texts of the school. The text of the Qurra thus should be read against the background of the increasing influence of the Shāfi $\overline{1}$ ideas and scholars in the sixteenth-century littoral.

As mentioned earlier, the author also wrote a commentary on the Qurra, and both texts are circulated together in the Islamic world as a single compilation. More than the basetext, this commentary became famous and celebrated among Shāfi $\overline{1}$ jurists of the Indian Ocean littoral as an intermediate textbook, reference, source for commentaries, supercommentaries, summaries, etc., thus furthering the circulation of textual and legalistic ideas of the Shāfi ' $\overline{1}$ cosmopolis and representing the rising interest in its doctrines. ${ }^{32}$ However, a few jurists did go back to the base-text to poetise and write commentaries on it, as the Javanese scholar 'Umar Nawawī al-Bantanī did in the late nineteenth century. ${ }^{33}$

Bantanī's Nihâyat al-zayn, the second text under our focus, is the only commentary on the Qurrat known and available down to us so far. ${ }^{34}$ Printed in Egypt in July I 88 I for first time, the text has been an important source of legal scholarship among the Southeast Asian students based either in the Middle East or in the Malay world itself. Bantanī does not mention his motivation for writing the text. He only says that through this he aims to help jurist colleagues "who are underprivileged like me". ${ }^{35}$ This reference to himself as "underprivileged" ( $q \bar{a} \sin \bar{i} n)$ is an expression of modesty. Although such self-denunciatory tropes are common in the Arabic texts, Bantan̄̄ was particularly known among his contemporaries for his humility. When Snouck Hurgronje, the Dutch Arabist, met him in Mecca in the late nineteenth century, he noted: "In social intercourse of any kind, he rather joins courteously in the conversation than dominates it, and never starts any scientific discussion without cause given by others. An Arab who did not know him might pass a whole evening in his society without noticing that he was the author of about twenty learned Arabic works". 36

Bantan̄ was born and brought up in Banten in West Java, and he moved to Mecca in I 828 after an initial education at the pesantrens (traditional centres of Islamic learning) of Java and a short career of teaching in his hometown. He stayed in Mecca as a student, teacher, author and muftī (law-giver) until his death. ${ }^{37}$ Through his extensive writings he

\footnotetext{
${ }^{32} \mathrm{On}$ its reception and circulation among the Shāfi '⿳亠 Muslims, see Kooria, 'Cosmopolis of Law', Chapter 6.

${ }^{33}$ Two Malabari scholars, Muhammad Musliyār bin Aḥmad Arīkal̄i (d. I952) and Anwar 'Abd Allāh al-Fadfarī, wrote poetised versions of the Qurra. I have not managed to locate the first poem, but the second poem has been published: Anwar 'Abd Allāh bin 'Abd al-Raḥmān al-Faḍfarī, al-Naz̧m al-wafì fì al-fiqh al-Shāfi ì (no place, 20Io); available at https://www.scribd.com/doc/I I 227998I/ النظماللوفي (consulted online Io May 20I9)

${ }^{34} \mathrm{I}$ came across a reference to another possible commentary from Somalia entitled Sharh Sa `̃d bin Mu'allif [li] Qurrat al-'ayn [sic] bi muhimmāt al-dīn. This commentary is a 444-page manuscript and is mentioned as one of the most circulated Shāfi' 1 texts in Somalia. But we do not know the name of its author or scribe, or even its date of composition. From its given title it seems a priori to be a commentary by one Sa ‘̄id bin Mu'allif. Only by being able to cross-check it against the other commentaries could make more interesting observations on the extent of the circulation and reception of the text.

${ }^{35}$ Nawawī al-Bantan̄̄, Nihāyat al-zayn fì irshād al-mubtadi' ìn bi-sharh Qurrat al- ayn bi-muhimmāt al-dīn (Cairo, I $88 \mathrm{I})$.

${ }^{36}$ C. Snouck Hurgronje, Mekka in the Latter Part of the 19th Century: Daily Life, Customs and Learning (Leiden, 2007), p. 290.

${ }^{37}$ For his biography, the major sources are Aboe Bakar Djajadiningrat, Taräjim 'ulamā' al-Jāwah, Leiden University Special Collections, Or. 7I I I, unpaginated; Hurgronje, Mekka; Chaidar, Sejarah pujangga Islam Syech Nawawi
} 
became an influential author widely appreciated in the Malay world. His oeuvre consisted of varied disciplines, such as law, mysticism, theology and ethics, and became essential textbooks in the pesantrens. Because of this a scholar went on to identify Bantani as the "intellectual master" of the pesantrens. ${ }^{38}$ His Nihāyat al-zayn also was taught and used in the pesantrens. It is one of his most famous legal texts among the Indonesian Shāfi ${ }^{\prime} \overline{1 s}^{39}{ }^{39}$ Martin van Bruinessen writes that it "is widely used" as a kitāb kuning (literally "yellow book", a generic term for a textbook of the pesantrens) while the base-text Qurra itself "never became popular" in the region. ${ }^{40}$

The Nihāya follows the long textual complex of the Shāfi $\overline{1}$ School by bringing together most of the known and some unknown texts into the legal discussions. While the Qurra avoided any form of engagement with earlier discourses, the Nihāya brings in several debates and discussions on each phrase and ruling of the Qurra. It takes the Qurra word by word, gives explanations for its legal complexity, and also elaborates on its sentence structures, syntaxes, phrases, etc. If the word under consideration happens to be a historical person or place it gives somewhat detailed accounts. It does all these through quotations and borrowings from the extensive textual corpus of the school. It makes this approach very clear in the preface: "Whatever is written in this book is none of my own. It is all taken from the wordings of [previous] authors". ${ }^{41}$ It goes on to say that its main source of reference is the Nihāyat al-amal, a lesser known text in the school written by Muhammad bin Ibrāhīm Abū Khuḍayr al-Dimyāțī. It also made use of other renowned texts of the school, such as the Tuhfat al-muhtāj and the Fath al-jawād of Ibn Hajar al-Haytamī (d. I 566), the Nihāyat al-muhtāj of Shams al-Dīn Muhammad al-Ramlī (d. I 596), and a commentary on the Ghāyat al-ikhtișār (also known as Matn, Mukhtaṣar and Taqrīb) of Abū Shujā' Aḥmad bin al-Hasan (d. I I97).

Bringing together passages from these diverse references into coherent narratives, the Nihayya articulated the arguments of the Qurra to an extent that addresses topics beyond the concern of primary students of Shāfi 's law. It became a dependable textbook and reference material for intermediate and advanced students of the legal school across the littoral. Although the main audience was the Southeast Asian students (mainly in Indonesia, but also in Malaysia, Thailand and Brunei), it was not limited to them alone. Students and practitioners from South Asia and the Middle East also have been using it. It has been printed in the Middle East several times, from the first to the most recent edition. ${ }^{42}$ In India I heard about the text for the first time from Bahā' al-Dīn Muhammad Nadwī, who was himself the author of texts on Shāfí $1 \overline{1}$ law circulated in Malabar. It used Arabic to reach beyond the immediate audience of a Malay-speaking world and was esteemed for its wider reception, an issue to be discussed further below.

\footnotetext{
Albanteni, Indonesia (Jakarta, I978); cf. Alex Wijoyo, 'Shaykh Nawawi of Banten: Texts, Authority, and the Gloss Tradition', PhD diss., Columbia University, I997.

${ }^{38}$ Abd Rahman, 'Nawawī al-Bantanī: An Intellectual Master of the Pesantren Tradition', Studia Islamika 3, no. 3 (I996), pp. 8I-II4.

${ }^{39}$ Wijoyo, 'Shaykh Nawawi of Banten,' pp. I73-I74.

${ }^{40}$ Martin van Bruinessen, 'Kitab Kuning: Books in Arabic Script Used in the Pesantren Milieu; Comments on a New Collection in the KITLV Library', Bijdragen tot de Taal-, Land-en Volkenkunde I46, nos. 2-3 (I990), p. 247.

${ }^{41}$ Muḥammad bin Ibrāhīm Abū Khuḍayr al-Dimyāṭ̂̄, Nihāyat al-amal li man raghib fì șihhat al- 'aqìdat wa al- 'amal (Cairo, I895); MSS, Umm al-Qura University.

${ }^{42}$ For a recent Middle East edition, see Nawawī al-Bantan̄̄, Nihāyat al-zayn (Beirut, 2002).
} 
The trajectory of the Qurra and its commentary Nihāya lies in contrast with the course of two other texts written in Malay: the Șirạt al-mustaqīm of Ranīrī and its indirect commentary Sabīl al-muhtadīn by Muhammad Arshad al-Banjārī, two most important Islamic legal texts written in Southeast Asia. ${ }^{43}$ There are many similarities between these two textual groups, but there are many differences. The most obvious one of course is the language, but also the themes covered in the Malay texts are limited. While the Qurra (and hence its commentary) dealt with all the usual topics of a Shāfi $1 \overline{1}$ text by engaging with the issues of rituals, transactions, marriage and crime, the Sirăt (and therefore its commentary) deals mainly with the laws concerning the rituals. It is not clear why its author Ranīrī decided to engage with this part exclusively, but it is evidently the most important part and often the starting point of any Islamic law-book. ${ }^{44}$ As this is the first known Islamic legal text written in Malay, he might have wanted to educate his audience on the fundamental rituals of Islam so that they will observe Islam closely following the prescriptions of the scriptures. The text indeed achieved its goal through the wide reception it found among Malay students of Islamic law. It is possibly 'the most copied Malay manuscript ever', with more than I75 copies surviving, and it has been printed several times in regions from Southeast Asia to the Middle East. ${ }^{45}$

Ranīiñ was born and brought up in Rander (in present day Gujarat in India) in a Hadramī Arab family that had been settled there for several decades. After his initial education in Gujarat he went to Yemen and Mecca for higher studies. Eventually he entered the court of the Aceh Sultanate to practise as a scholar and teacher. Muhammad al-Hāmid, mentioned above, was his uncle, so the place and its intellectual atmosphere must have been familiar to him earlier. Upon his arrival his major concern was the mystical orientation of the region and he opposed the predominant mystical ideas and practices of certain leaders and their followers. His major targets were the mystic Hamza Fansūrī and his disciples including Shams al-Dīn Samatrānī. He called their adherence to the mystical ideas of wahdat al-wujūd as pantheistic and hence heretical. By amassing support from the royal household, especially of the then ruler Iskandar Thānī (r. I636-4I) who appointed him as the chief judge in the kingdom, he argued against his opponents, had many of them executed and their books burned in front of the main mosque in Banda Aceh. After a few years, however, Ranīin had to meet intense criticism from the followers of this mystical order, and they defeated him in debate. ${ }^{46}$ Consequently he left Aceh for Gujarat, where he lived until his death on 2I September I658. During his seven-year stay in Aceh he wrote fourteen books on diverse topics,

\footnotetext{
${ }^{43}$ The other earliest known works in this category are Mir'āt al-țulläb fì tashīl ma 'rifat al-ahkām al-shar 'iyya li Malik al-Wahhāb by 'Abd al-Ra' ūf Sinkilī (d. I693), who wrote it at the request of the Acehnese queen Șafiyat al-Dīn Tāj al-'Ālam (r. I64I-I675); and Safinat al-ḥukkām fì takhț̣s al-Khașạ̄m written in I740 by Jalāl al-Dīn bin Shaykh Muhammad Kamāl al-Dīn bin al-Qāḍī al-Tarusānī. On a comparative study of these two texts and their importance in the Southeast Asian Islamic legal tradition, see Chambert-Loir, 'Islamic Law in I 7th Century Aceh'; idem, "Aceh in the $17^{\text {th }}-19^{\text {th }}$ Centuries: Two Cadis, One Historian" (unpublished article). I am thankful to the author for showing this manuscript to me.

${ }^{44}$ Nūr al-Dīn al-Ranīrī, Sirāt al-mustaqīm.

${ }^{45}$ Chambert-Loir, 'Islamic Law in I7th Century Aceh', p. 56.

${ }^{46}$ On these debates and reasons that led to his departure, see Syed Muhammad Naquib al-Attas, Rānīi and the Wujüdiyyah of 17th century Acheh (Singapore, I966); Takeshi Ito, "Why did Nuruddin ar-Raniri leave Aceh in I054 A.H.?', Bijdragen tot de Taal-, Land-en Volkenkunde I34 (I978), pp. 489-49I. On his major opponent who defeated him in his debate, see Sher Banu A.L. Khan, 'What happened to Sayf al-Rijal?', Bijdragen tot de Taal-, Land-en Volkenkunde I68, no. I (2012), pp. Iоо-і I I.
} 
including mysticism, theology, law and history. The Sirāt is his most important legal text, exclusively concerned with discussions of Shāfi ' $\overline{1}$ laws. He had discussed law in his other works, either in passing or in detail, but none of those discussions was an exercise in elaborating on law exclusively.

The Sirat is a comparatively long text with extensive discussions on different ritual laws. It generally follows the chapter framework of the Shāfi $\overline{1}$ texts, starting with a section (kitāb) on purity, then moves on to prayer, almsgiving, fasting, retreat to the mosque and pilgrimage. But it also has sections not usually found in texts on ritual laws. Following the discussion on pilgrimage it has one section on hunting and slaughtering and another on foods, themes which usually appear in Shāfi' $\overline{1}$ texts following the discussions on criminal laws. There are eight sections in total, with each section divided into several chapters (bābs) with their subchapters, or articles (fassls). For example, the section on purity is divided into chapters on impurity (najas), ablution, reasons of impurity, bathing, dry ablution (tayammum), menstruation and postnatal bleeding; the first of these chapters (on impurity) is divided into four sub-chapters.

In his introductory lines Ranīrī talks about what motivated him to write such a text. He says that there is no such text on Shāfi '⿳亠 law for the use of Malay Muslims, many of whom do not understand Arabic. By writing this text for them he expects rewards from God for the virtues it disseminates, because the Prophet has said that one who guides people to good things will earn the same reward as the person who actually does good things. ${ }^{47}$ The Sirăt is based on such major sources as the Minhāj of Yahyā bin Sharaf al-Nawawī (I233-I277) and its various commentaries and summaries: these include the Manhaj and its commentary Fath al-Wahhāb, both written by Zakariyā al-Anșārī (d. I520); Hidāyat al-muhtāj (Tuhfat al-muhtāj) of Ibn Hajar al-Haytamī; Anwār li a 'māl al-abrār of Yūsuf bin Ibrāhīm al-Ardabīīì (d. I377); and 'Umdat al-sālik wa 'uddat al-nāsik of Aḥmad bin al-Naqīb (1302-68). In selecting Ibn Hajar's commentary as one of his source rather than the contemporary Egyptian commentaries of Ramlī and Khațīb Sharbīn̄ì (d. I 570), he shows an affinity with the Meccan version of Shāfi 'ssm, a split that emerged in the school in the late sixteenth century. ${ }^{48}$ The author drew upon a very wide repository of Shāfi $\overline{1}$ texts written in Arabic in the thirteenth to sixteenth centuries to prepare this first Islamic legal text in Malay. This textual interconnectivity is evidence of ever widening networks of Shăfi $\overline{1}$ texts and ideas spreading across the maritime littoral.

The Sabīl al-muhtadīn by Muhammad Arshad al-Banjārī, the fourth text in our list, was written in I779 at the request of Sultan Taḥmīdullāh bin Tamjīdullāh of Banjar as a commentary on the Siratt. In the preface the author praises the Sirăt by connecting the feature of translating it to the Shāfi ' $\overline{1}$ textual cosmopolis that "it is one of the best texts translated (Ar. mutarajima; Mal. bhasakan) into the Jāwī language, because its legal discussions (mas $\left.\bar{a}^{\prime} i l\right)$ are excerpted from several legal texts; it amalgamates both scriptural and rational evidences, and the people have gained a lot from it and they have received it very well". ${ }^{49}$ Despite this appreciation of his source, he also raises indirect criticisms about the

\footnotetext{
${ }^{47}$ Ranīrī, Sirāt al-mustaqìm, pp. 4 and 6.

${ }^{48}$ On the details of this division within the school, see Kooria, 'Cosmopolis of Law', Chapter 5.

${ }^{49}$ Muhammad Arshad al-Banjārī, Sabīl al-muhtadīn li tafaqquh fì amr al-dīn (Mecca, I 892), p. 3.
} 
book and its uses of Acehnese words and phrases. His criticism is mainly aimed at its scribes who made several mistakes when they copied the text: "In some [such phrases] in it there is alteration and variation; in some those have been dropped. All those changes have been made by stupid copyists. Therefore, the copies and phrases differed; some of those were ruined; it has become almost impossible to obtain a correct copy (Ar. nuskhat șahīha; Mal. nuskha yang sahiha) ascribed to the author, and a correct copy cannot be distinguished from a wrong copy except by experts. But where are the experts in these places and in these times? For determinations they have decreased, intelligence has reduced, and minds have become confused". Arshad al-Banjārī sets out these reasons as the context into which he wrote his commentary, but his major motivation was the request from the sultan who wanted to have a text on Shāfi ${ }^{\prime} \overline{1}$ law in Jāwī. He says that he wrote the text following the sultan's orders, even though he is not fully eligible to write such a text as his "knowledge is poor, confidence weak, comprehension feeble and cognisance muddled". After a short prayer for the text to be accepted as a meritorious activity in the life hereafter he begins the legal discussions. His first chapter on ritual impurity follows the same pattern and order of the Sirāt.

The Sabill is in many ways an indirect commentary on the Sirät, because it does not aim to comment on each word and phrase of the Sirät, which is a convention of the direct commentaries in the Shāfi ${ }_{1}^{1}$ School and broadly Islamic law. Instead, it follows the overall structure and contents of the Siraț but builds upon its own arguments and rulings. In addition to the Sirât's sources, it also brings in sixteenth-century Egyptian commentaries, the Nihâyat al-muhtäj of Ramlī and the Mughnī of Khațīb Sharbīnī as sources. This is an interesting addition as it bridges the gap between the Meccan and Cairene versions of the school by referring to Ramlī, Khațīb Sharbīn̄̄ and Ibn Hajar al-Haytamī in its discussions. On the very opening of the legal discussions, for example, it brings together both Ibn Hajar and Ramlī. ${ }^{50}$ Such a synthesis of two sub-schools is typical of a larger attempt in the eighteenth century by the Middle Eastern jurists such as Muhammad al-Kurdī. The synthesis flourished in the nineteenth and twentieth centuries, in which the Nihâya of Nawawi al-Bantanī also took part. Together with other Arabic sources Banjārī also mentions that he has used "several other base texts, commentaries, and super-commentaries in Malay", but he does not specify what those Malay texts were.

\section{Microcosmoi of Islamic Legal Cosmopolis}

For all these four authors from monsoon Asia, language was an important element in their scholarly careers and communications with both the local and a wider audience. Their attentiveness to language contributed to the success of the Shāfi ${ }^{\prime} \overline{1}$ School and Islamic law in general in the Indian Ocean littoral. In monsoon Asia the microcosmoi of Arabic and Malay enabled the production and circulation of juridical texts, ideas and scholarship. If the role of Arabic was taken for granted in the Islamic sphere among both historical participants and contemporary observers, the role of Malay as a lingua franca has been largely neglected, especially in Islamic legal historiography. The four texts and authors under our current focus

${ }^{50}$ Banjārīi, Sabīl al-muhtadīn, p. 5 
exhibit deliberate choice in their selection of languages, using Arabic, or Malay, or both. This is primarily because these languages were not native to them or to their immediate audiences. Both languages were learned languages for most people in South and Southeast Asia, restricted in use to shared spaces of scholarly, mercantile, political, and diplomatic contacts, in which people from different places and backgrounds communicated with each other. Arabic was commonly used in most Islamic educational institutions, particularly in legal colleges, for jurists believed that a command of Arabic was integral to the proper understanding of Islamic law "because the Shart'a is in Arabic". 51

In contrast, Malay appealed as a lingua franca, primarily in Southeast Asia but also spreading beyond to East and South Africa and East Asia through exiles, scholars, traders and pilgrims in the seventeenth to nineteenth centuries. Both the local Southeast Asian communities and diasporas used Malay to study Islam and they produced a significant amount of religious and non-religious texts during this period. Scholars who wanted to address the Southeast Asian communities had to master Malay to communicate their ideas smoothly. Those who learned the language and produced texts in it could and did influence the course of Islam in the long run. It was a very difficult task to translate Arabic legal vocabularies and texts into Malay even for native speakers, as there were hardly any precedents in the seventeenth and eighteenth century and producing an Islamic legal language in Malay was still in its infancy. Most authors studied Islamic law in Arabic, using Arabic texts and/or while living in Arabia for many years. Consequently their works showed a high influence from Arabic in grammar and vocabulary, a dialect often identified as Kitab Malay or the Malay of religious texts. ${ }^{52}$ Although such texts were difficult to read for an average Malay student without some background in Arabic, the texts did provide a window for many of them to master the laws of their religion in a language closer to them than Arabic. Such deliberately vigorous use of Arabic and Malay led to the success of the Shäfi $\bar{\imath}$ School in the Indian Ocean littoral.

The Qurra and its commentary the Nihāya do not directly mention selecting Arabic, for they must have taken the primacy of Arabic for Islamic legal writing for granted. Though the authors of these books were born and brought up in Malabar or Java they knew that Arabic mattered for the recognition of their works not only among their immediate audiences in Malabar, Java or Mecca, but also in a larger world beyond. Both texts communicated to their non-Arabic speaking audiences as a textbook read and taught through the teachers who had mastered the language. By choosing Arabic rather than regional languages (Malayalam or Javanese) they demonstrated their intention of communicating with the larger Indian Ocean world, where Arabic was still a lingua franca. Using Arabic also enabled their work to be incorporated into the broader Middle Eastern and non-Middle Eastern Islamic networks of scholars, texts and ideas. The Nihaya is one of the earliest legal texts written in Arabic by a Javanese scholar. Up until then almost all the legal texts available from the archipelago are in Malay, including the Șirāt, the Sabīl al-muhtadīn or the Mir'àt al-țulläb. Arabic contributed to raising the status of this manual to an important legal text in Islamic

\footnotetext{
${ }^{51}$ Imām al-Haramayn̄̄ 'Abd al-Malik Juwayn̄̄, Nihāyat al-mațlab fì dirāyat al-madhab, (ed.) 'Abd al-'Aẓīm Maḥmūd al-Dayyib (Jiddah, 2007), vol. I 8, p. 478.

${ }^{52}$ Chambert-Loir, 'Islamic Law in I 7 th Century Aceh', passim.
} 
educational institutions, such as the pesantrens in Indonesia and beyond. Studying Islamic law in Arabic was, and continues to be, the pedagogical norm in legal colleges.

The simplified language of the Qurra enabled its author to write a commentary within a short period. The commentary entitled Fath al-mu ìn became the most celebrated Shāfi 'i text written by an Indian scholar, and it has been circulated from East Africa to East Asia in its own right and through its several commentaries. Ironically, the language formulations of the Fath were rather complicated for non-native speakers of Arabic. This problem deterred its audience from understanding the base text and the commentary and many scholars and teachers of Shāfi '̄ism in the littoral complained that it was a difficult (Bah. sulit) text. In several ways this issue also emerged in the dissemination of the Nihāya. It received a restricted coverage within the Malay world when compared with the circulation of Malay legal texts: they became very important for the survival of Shāfi 1 ism there.

In the preface of the Sirạt al-mustaqìm, Nūr al-Dīn al-Ranīrī mentions that he chose to write it in Malay because there was nothing of that sort in the language and his colleagues asked him to write one. ${ }^{53}$ The "request from colleagues" is a usual trope in Islamic texts that might not correspond to actual requests, but to a wider demand for a text like that. Its language is somewhat complicated, mixing highly Arabicised Malay vocabulary alongside Acehnese and non-Acehnese terms. In the preface it gives the Arabic text first, followed by an interpretative translation in Malay. However, once it comes to actual legal discussions it uses Malay alone; any complete sentences in Arabic are marginal. The very highly Arabicised Malay (or Kitab Malay) has an abstruse vocabulary which a lay reader might find difficult to follow. What is more, the Malay is highly influenced by Bahasa Aceh and Persian and Urdu. ${ }^{54}$ Arshad al-Banjārī says that non-Malay and non-Arabic terms are inserted by the "stupid copyists", but we cannot validate this statement for we do not have the original manuscript written by Ranīrī. It is quite possible that Ranīrī himself used such terms, as he was based in Aceh during its writing and he had a South Asian upbringing where Persian and Urdu was predominant among the intellectual and political elites and he was well-versed in all these languages.

Language difficulties motivated Arshad al-Banjārī to write his commentary the Sabīl al-muhtadin , in which he explained how the high influence of Acehnese and Arabic vocabularies in the Sirāt makes it a difficult text to follow. ${ }^{55}$ The Sabīl thus became an important text of Shāfi' $\overline{1}$ law which was studied, taught and circulated widely in the Islamic educational realms of Southeast Asia. The text was taught in the intermediate level of Malay Islamic law colleges, often after the students finished studying the primary texts such as the Safinat al-najat. ${ }^{56}$ The most advantageous aspect of both texts is that they can be read and studied without a strong command of Arabic. Although a knowledge of Arabic is an added advantage in reading the texts, it is not at all mandatory. One would not miss anything by skipping the Arabic parts, as all the Arabic sentences have been translated into Malay.

The fact that the Sirăt is one of the most copied Malay manuscripts in the eighteenth to twentieth centuries demonstrate its wider receptivity and usage among the students and

\footnotetext{
${ }^{53}$ Nūr al-Dīn al-Ranīrī, Sirāt al-mustaqìm.

${ }^{54}$ For example the use farman in Allah farman for "qāla Allah".

${ }^{55}$ Banjārīi, Sabīl al-muhtadīn.

${ }^{56}$ L.W.C, van den Berg, 'Het Mohammedaansche godsdienstonderwijs op Java en Madoera en de daarbij gebruikte Arabische boeken,' Tijdschrift voor Indische Taal-, Land-en Volkenkunde 3 I (I886), pp. 5I8-555.
} 
scholars of Islamic law and its Shāfi 1 stream. ${ }^{57}$ From the late nineteenth century onward it has been often reprinted multiple times, sometimes in the margin of the Sabil al-muhtadin which was usually printed without the Sirat. ${ }^{58}$ The printed editions circulated not only in the Malay Archipelago but also in Sri Lanka and South Africa. This indicates both texts received a widespread recognition owing to their exclusive use of Malay. ${ }^{59}$ In the Islamic educational centres among the Malay communities in Southeast Asia and the wider Indian Ocean world the text propagated Shāfi ${ }^{\prime} \overline{1}$ legalism just as much as Shāfi ${ }^{\prime} \overline{1}$ legalism promoted the relevance of the text. This mutually complimentary process was influenced partly by the uses of Malay. It proves that language contributed to a wider receptivity and acceptance among Malay Shāfi'is in the littoral, stretching from the Cape Malays in South Africa to Maguindanao and Sulu in the Philippines.

This duality of Arabic and Malay microcosmoi in the history of Islamic law should be taken into account more often, not only to understand how and why the Shāfi '̄ school spread and succeeded in the Indian Ocean littoral, but also to understand the multidirectional, multi-linguistic and multi-ethnic compositions in the history of Islam in the littoral. Instead of seeing its history in "peripheries", as a single story of Islamic expansion the hands of Arabs and through Arabic, we need to take into account the microcosmoi that helped the ultimate survival of multiple doctrines. As the Arabs and Arabic played a role in the history of Islam in South and Southeast Asia, the local communities and languages also, perhaps even more, advanced the support for their religion and its survival by the works they produced, the debates they initiated, the sermons they delivered, all in the languages the people could understand and relate to. ${ }^{60}$ While a regional lingua franca such as Malay facilitated the subcontinental recognition of the ideas and doctrines they upheld, a transregional lingua franca such as Arabic enabled the regional scholars to communicate with the larger world of Islamic scholarship. This simultaneous selection of more than one language, in this case Arabic and Malay, contributed to the preservation of Shāfi 's̄ legalism in the maritime littoral.

\section{Conclusion}

Involving some other language or languages along with Arabic has been crucial to the sustainability of the intellectual networks of Islam and particularly of those of legal schools, as we see in the Hanafì realms of South Asia and Near East and the Shīì sphere of Persia, where the production of legal texts in Arabic complemented those in Turkish and Persian,

\footnotetext{
${ }^{57}$ For a list of its numerous manuscript copies from the Malay world and beyond, see Jamalluddin bin Hashim and Abdul Karim bin Ali, 'Kitab Sirāt al-mustaqīm oleh Shaykh Nūr al-Dīn al-Ranīrī: Satu Soratan', Journal Fiqh, 5 (2008), pp. I97-215.

${ }^{58}$ For example, see two editions of the Sabīl al-muhtadīn with and without Sirāt in the margin. I 882 with Sirăt, and I9I2 edition without it.

${ }^{59} \mathrm{On}$ the usage of the text as an important source law for the Malay Muslims of South Africa, see John S. Mayson, The Malays of Cape Town, South Africa (Manchester, I855), p. I7; on its presence in Sri Lanka, see Ronit Ricci, 'Remembering Java's Islamization: A View from Sri Lanka', in Global Muslims in the Age of Steam and Print, (ed.) James L. Gelvin and Nile Green (Berkeley, 20I4), pp. I90, 20 I.

${ }^{60}$ This argument stands in line with the latest literature on the contributions of Southeast Asian communities in the making of Islam and its laws. See for example, Hussin, Politics of Islamic Law; Francis R. Bradley, Forging Islamic Power and Place: The Legacy of Shaykh Daud bin 'Abd Allah al-Fatani in Mecca and Southeast Asia (Honolulu, 2015).
} 
as just one example. Shāfi îsm did this through scholars with the attention and ability to write in Arabic or in the regional lingua franca. As we have seen, the choice of language was not easy for these authors. All had different native languages, but they chose to write in Arabic or Malay in order to address larger audiences beyond their immediate realms. Coming from a Malayalam-speaking sphere, Zayn al-Dīn wrote in Arabic. His commentator Nawawī al-Bantan̄i did the same though coming from a Javanese sphere. Ranīī took a different course: he came from an Arab family based in Gujarat where Gujarati was the predominant language, but wrote in Malay. For his commentator Banjārī Malay was a lingua franca and his native language was Banjar. This appeared to be an advantage for all of them in the long run, as their texts were circulated in the larger microcosmoi of the Shāfi '⿳亠 cosmopolis of monsoon Asia.

An open approach among Shâfi $\overline{1}$ jurists to navigate between these languages played an important role in making Shāfi ${ }^{\prime}$ ism the dominant legal school in the Indian Ocean world from the sixteenth century onwards. This Shāfi 'isation process coincided with the larger conversion process that was going on in the same regions where the school stood as the main, if not the only, framework for new Muslims to assimilate the teachings of Islam. The increasing circulation of Shāfi $\overline{1}^{1}$ Muslims from Yemen, Persia, Hijaz, Egypt, Iraq and the Levant across the oceanic littoral opened up the doctrines of the school to Asian and African followers. They in turn spread the school through their own frameworks utilising the same maritime networks through such groups as Malabaris, Gujaratis, Tamils, Malays, Swahilis and Habshis. The textual interconnectivities between the Qurra, written by a Malabari jurist, and its commentary the Nihāya, by a Javanese/Meccan scholar, as well as between the Sirăt by a Hadramī/Indian scholar and its commentary Sabīl al-muhtadīn by a Banjari/ Malay scholar, demonstrate multi-directional journeys within the larger cosmopolis of Islamic law through intersections between language microcosmoi.

As much as languages facilitated the transregional interactions of political, commercial and religious groups of diverse origins, the laws also ensured an easy continuum of exchanges of sources, texts, doctrines, rules, ideals and vocabularies among people from different backgrounds and interests. The interconnected cosmpolises of languages and laws thus provided common grounds for the itinerant groups of the Indian Ocean, and they in turn translated and transferred what was foreign into local and local into foreign. In the Islamic legal cosmopolis that prevailed in the premodern Indian Ocean, the Shāfi ${ }_{1} \overline{1}$ stream dominated these exchanges within and outside the Muslim communities from the sixteenth century onward, along with the intensification of conversions into Islam in coastal South Asia and island Southeast Asia. The contributions of home-grown Muslim jurists to the Islamic textual longue durée through their critical engagements with the laws and languages of Islam have produced a vast corpus of the literature that modifies the existing understanding of Islamic historiography, especially of legal historiography, of the oceanic littoral. <mahmoodpana@gmail.com>

MAHMOOD KOORIA

University of Leiden 